\title{
REASONS AND CIRCUMSTANCES THAT LEAD TO THE NON- USE OF MEDIA BY YOUNG PEOPLE AND THEIR FAMILIES
}

\author{
Maria José Brites \& Cristina Ponte
}

\begin{abstract}
This article argues for the need to pay attention to the dynamics of refusing and rejecting the use of media to better understand a highly mediatized consumer society. The theoretical background utilizes resistance to the media, family contexts of socialisation and mediated society. We analysed 18 interviews carried out in Portugal - undertaken as part of wider research project involving 40 young people and their families, on their relationship with the media regarding citizenship rights -, which showed signs of non-use of media. This article characterises these individuals, their contexts and motives. Through identifying refusal of the internet, social networks, news and television, we arrive at distinct five types: "I do not like and I do not want to use"; "At this stage of life, no!"; "Split between I can't have and I can't buy it"; "I don't want to draw attention to myself and don't want to get 'hooked"; and "Doing something different and doing it better".
\end{abstract}

\section{MOTIVAÇÕES E CIRCUNSTÂNCIAS QUE LEVAM A NÃo USOS DOS MÉDIA POR JOVENS E SEUS FAMILIARES}

\section{Resumo}

Neste artigo argumentamos pela necessidade de atenção a dinâmicas de recusa e de rejeição de utilização dos média para melhor se compreender a sociedade de consumo profundamente mediatizada. Seguimos um suporte teórico sobre resistência aos média, contextos familiares de socialização e sociedade mediatizada. Analisamos 18 entrevistas realizadas em Portugal - conduzidas no âmbito de uma investigação mais vasta com 40 jovens e seus familiares, sobre a sua relação com os média na perspetiva de direitos de cidadania -, que evidenciaram sinais de não uso dos média. O presente artigo caracteriza estas pessoas, os seus contextos e motivos. Identificando recusas da internet, das redes sociais, das notícias e da televisão, chegamos a cinco tipos: "Não gosto e não quero usar"; "Nesta fase da vida, não!"; "Entre o não posso ter e o não posso comprar"; "Não dar nas 'vistas' e não ficar 'agarrado'" e "Fazer diferente e fazer melhor". 


\section{INTRODUCTION}

In the early 1960s, when the Argentinian cartoonist Quino thought up a strip suggesting that his well-known character Mafalda did not have a television set, he never anticipated how such a strip would be important in reflecting and parodying the quasiumbilical relationship between humans and screens. What was implied in that strip was the choice of someone, wise among her peers, to say no to a dominant culture. Mafalda did not do it alone: she grew up in a family environment which had chosen this option.

The decades went by and new screens were added to the television. The media has become more connected, ubiquitous, omnipresent, with an accelerated pace of innovation: we are living highly mediatized times (Couldry \& Hepp, 2017; Hepp \& Hasebrink, 2018). Undoubtedly, this permanent mediated connection facilitates relations and interactions, and presupposes a fundamental societal value (Livingstone, 2014). But the other side deserves equal attention: who does not want and who cannot enjoy the conditions provided by this context.

This article is based on the perspective that it is necessary to understand disconnectivities to understand immersivity. It is not enough to look at consumption, it is also necessary to look at non-consumption since it is only through understanding both sides - increasingly viewed in terms of mobility (Araújo, Cogo \& Pinto, 2015) and as fluid (Syvertsen, 2017) - that we can understand mediatized society (Woodstock, 2014). If the contexts of exclusion due to socio-economic reasons have been explored (Brites, 2015), we also sought to better understand the still hardly studied contexts of resistance and self-exclusion (Neves \& Rente, 2017; Schrøder \& BlachØrsten, 2016).

There were signs of resistance and/or impossibility of using the media (television, internet, social networks) that led to the analysis that underlies this article. Among the 40 interviews carried out in late 2015 and early 2016, which had the aim of assessing how young people and their adult family relatives referred to their relationship with the media from the perspective of citizenship rights, we found 18 situations where one of the members of the family pair claimed not to make any use or where both were similar in their use of communication and content, which they stated they ignored.

Before attempting to systematize the motivations and constraints behind these signs of exclusion, it is important to bear in mind the particular media context within which such data arose. In Portugal the massive arrival of audiovisual and digital media in homes occurred later than in other European countries and television still is the hegemonic and more connected medium (Burnay \& Ribeiro, 2016).

If, among younger internet users (15-24 years), internet access is almost universal, above this age there are marked differences. Statistical data at the time of the study indicated that while more than half of females (57\%) did not use it, for males the value for non-users was less than half (43\%). The generational gap started at $45-54$ years of age, with more than half not using it. This was accentuated in the subsequent age groups. More than two-thirds of those who did not study beyond basic education did not use the internet, for $13 \%$ among those who had completed the $12^{\text {th }}$ grade and $7 \%$ among those with higher educational studies (INE, 2015). 
On the other hand, leadership of Portuguese internet users in social networks stands out in European terms: more than three quarters have used them, above the European average $(57 \%) ; 98 \%$ of internet users who used social networks had a profile on the Facebook network, with most having more than hundreds of "friends" (INE, 2015).

Regarding the consumption of news in Portugal, in 2016 a report from the Reuters Institute (Newman, Fletcher, Kalogeropoulos, Levy \& Nielsen, 2017) indicated that the country was situated close to countries in the North of Europe regarding its rejection $(22 \%)$. This is well below Turkey, the country with the highest level of rejection (57\%). The rejection figures pointed out by the Portuguese are also below the average found in that report, in which almost half $(48 \%)$ reporting that the news had a negative effect on their mood, followed by a lack of confidence in its veracity (37\%). According to the report from OberCom (2017), associated with the Reuters Institute study, among the reasons for the Portuguese avoiding news are wanting to avoid negative influences (37\%), distaste for certain images $(24 \%)$ and not trusting it (20\%).

It should be noted that in the years preceding these interviews, Portugal had been going through a severe economic crisis, with families from all social sectors experiencing various constraints with a possible impact on their media practices.

\section{MEDIA PRACTICES AND FAMILY DYNAMICS}

We started this text by recalling the difference between Mafalda and her peers regarding television and we briefly mentioned the family environment. Let us analyse this point in a bit more detail. In considering family dynamics in mediatization processes (Krotz, 2009) and generational transmission (Buchner, 2003) important concepts include cultural capital and distinction, from Bourdieu (2003), social configuration and personal or habitus formation, both from Elias (1987). The concept of cultural capital, in relation to other forms of capital - social, educational and economic - describes the changes in the life opportunities of people caused by the development of the means of communication. The concept of social configuration - of which the family is a recurrent example - highlights interdependencies between members whose experiences and actions are affected and who are also influenced by their contexts. In interaction with the family, the formation of the personality or habitus is the process through which the individual corresponds to specific norms that are defined by the members of this configuration.

Although family members have democratized their relationships (Beck, 1997; Beck \& Beck-Gernsheim, 2002), family relationships continue to be marked by parental expectations to provide their children with certain personal and social paths. This is particularly visible in the middle classes. The search for a distinction from other families and the accumulation of cultural capital mark their access to material and immaterial goods such as knowledge or formal education. Buchner (2003) highlights family micro-cultures as vital spaces for their members, both in terms of opportunities and constraints.

The relationship of families with television is illustrative of these processes. With the popular classes having appropriated it with enthusiasm, it aroused reservations 
among the elites who felt that its contents would not be of sufficient quality and could even cause damage to the upbringing of younger generations. The history of television has included recurring concerns about violent content deemed unsuitable or harmful for democracy and for the young (Milner, 2002; Postman, 1985/2005; Putnam, 2000).

News, especially television news, sometimes provokes resistance, rejection or disregard. Helgerud (2017) identifies three explanations for low levels of interest in the news: indifference towards content and form; need to prioritize time management; avoiding or rejecting depressing news, as noted in the studies of Schrøder and BlachØrsten (2016) and Moeller (1999). A depressing social environment - economic crisis, catastrophe also has an impact on resistances and denials. Information saturation may be another factor.

If monitoring current affairs has a perennial root in the relationship of audiences who have sought media information appropriate to their interests - from reading the newspaper printed in the morning to the ritual of television news followed together, today this monitoring is undertaken through connection with continuously updated content which is available everywhere.

Unlike television, in its early days the internet was valued in a celebratory fashion (Castells, 2008; Jenkins, 2006). With web 2.0 concerns spread to contacts provided by the medium and to user-generated content. A few years after they had emerged as communities of interest, digital social networks contributed to feed data connectivity (Dijck, 2013). The pressure to connect has become so commonplace in mobile apps that many internet users ignore the logic of producing economic value which underlies this.

Concerns about resisting the pressures of the media landscape are narratives common to other political, social and cultural challenges, according to Syvertsen (2017). With extensive work on resistance to the media, the author points out that this is often linked to a negative conceptualization, "seen as a form of panic, an irrational reaction, caused by technophobia, fear, hysteria or social marginalization" (Syvertsen, 2017, p. 4). However, the author contrasts the need to consider some form of resistance as necessary in a context of major mediatization: "in an era of ubiquitous media, we all need a measure of resistance, or at least a strategy for self-regulation, to prevent media from being too invasive" (Syvertsen, 2017, p. 97).

A recent qualitative study of young adults not using social networking sites (Neves \& Rente, 2017) highlighted the diversity of non-uses, their contingencies and their potential transition. Informed by an empirical analysis, the authors drew up three ideal types for this voluntary non-use: intentional, which includes a considered choice regarding exclusion; imposed, which results from pressures experienced from this exclusion; and instrumental, which combines non-use with use for specific purposes. This typology will also illuminate the analysis on the forms of non-use reported by this article.

Before we see which types of resistance and towards what, which were found in this group of young and mature adults connected by family ties, we will introduce the methodology used to carry out the analysis. 


\section{MeTHODOLOGY}

As we have indicated, this analysis started with an initial sample of 40 individuals interviewed between November 2015 and April 2016, regarding news consumption and media usage, as part of postdoctoral research work. As it is a qualitative and participative research work, we opted for semi-structured interviews and have provided fictitious names, to maintain the anonymity and confidentiality of participants. As shown in the literary review, later studies continue to validate the data from 2015-2016 and show the importance of looking at those resisting the media. Considering the economic and social crisis experienced in Portugal (2011-2014), the aim was to carry out research into distinct socio-economic contexts: a middle-class school, which was carrying out a project promoting daily citizenship; and a support centre for young people at risk of social exclusion. In both situations, the young people were invited to include one of their family members in the study, if they so wished, which did not happen in all cases. When a family pair was formed, the interviews were carried out separately, to allow for information to be matched.

In the transcription of the 40 interviews, we found extracts which pointed to forms of resistance, rejection and impossibility of such consumption, by 18 respondents: seven young people, five female and two male; 11 adults aged between 45 and 61, seven female and four male. Respondents who said they liked something less (news, internet, social networks) were not included in this group. We only included those who - clearly - actively resisted, rejected or were unable to access something and for whom these situations implied a reflection on and specific management of their daily lives. If we had included those who indicated they liked something less, the group would be a little larger, especially regarding the news.

Further analysis was carried out in NVivo 11.3.2 1888. Topics related to the refusals, resistances and impossibilities identified were considered and their relationship to theory. We based ourselves on grounded theory, letting the data speak for itself, reflecting and opening new clues through theorising (Seale, 2004), and topic analysis (Attride-Stirling, 2001), since they have points in common for information organization (Attride-Stirling, 2001; Corbin \& Strauss, 1990).

The categories were induced through the data (Amado, Costa \& Crsoé, 2014). Following Bardin's (2009) indications, we first recognized the differentiations and in the following phase we regrouped the data elements into major topics/categories, indicating the common features characterizing these. Some participants fell into more than one category because they indicated various resistances or rejections.

\section{ANALYSIS OF THE RESULTS}

The hegemonic social network Facebook was the element that provoked most resistance, being indicated by half of the individuals in the group, irrespective of age. In turn, the internet was not considered worthy of their attention by five individuals, with age having a significant weighting. Four had a low opinion of television, and three concerning the mobile phone and certain news content. 
We organized the individual responses and those related to family dynamics into two tables. Each one shows participants, their age, level of schooling, what they mention that they do not make use of and how they describe, in their own words, the environment regarding access to information at home and uses of the internet. Let us now consider the table concerning resistances shown only individually.

\begin{tabular}{|c|c|c|c|c|c|}
\hline PARTICIPANT & AGE & $\begin{array}{l}\text { EDUCATION AND } \\
\text { PROFESSION }\end{array}$ & $\begin{array}{l}\text { RESISTANCE/ } \\
\text { REJECTION }\end{array}$ & MEdiA ENVIRONMENTS & USES OF THE INTERNET \\
\hline Arminda & 59 & $\begin{array}{l}\text { Completion of } \\
\text { Secondary Educa- } \\
\text { tion; saleswoman }\end{array}$ & $\begin{array}{l}\text { Internet; } \\
\text { "sad news" }\end{array}$ & $\begin{array}{l}\text { Many books at home, of } \\
\text { various kinds, including art. As } \\
\text { regards television, she likes to } \\
\text { watch movies and cartoons. }\end{array}$ & $\begin{array}{l}\text { She just uses the internet when } \\
\text { she has to, at work. She thinks } \\
\text { she has a good memory and } \\
\text { remembers everything. She } \\
\text { has a mobile phone that does } \\
\text { not have internet access. }\end{array}$ \\
\hline Antónia & 49 & $\begin{array}{l}\text { Completed Pri- } \\
\text { mary Education; } \\
\text { retired (canteen } \\
\text { and cleaning) } \\
\text { and cleans }\end{array}$ & $\begin{array}{l}\text { Facebook; } \\
\text { internet }\end{array}$ & $\begin{array}{l}\text { Her computer broke down at } \\
\text { home and she did not have } \\
\text { the money to fix it; she has a } \\
\text { mobile phone without internet } \\
\text { access; she sometimes has ac- } \\
\text { cess to the printed newspaper } \\
\text { Jornal de Notícias. She watches } \\
\text { the news on TV, and she consi- } \\
\text { ders that it provides company. }\end{array}$ & $\begin{array}{l}\text { She sometimes uses her } \\
\text { grandson's tablet, especially to } \\
\text { see which male friends he has } \\
\text { online (fear of paedophilia); she } \\
\text { asks her grandson to show her } \\
\text { and he does so, without questio- } \\
\text { ning what is being asked of him. }\end{array}$ \\
\hline Filipe & 45 & $\begin{array}{l}\text { Completion of } \\
\text { Secondary Educa- } \\
\text { tion; technician at } \\
\text { Porto Town Hall }\end{array}$ & Facebook & $\begin{array}{l}\text { At home there is television } \\
\text { and school books. He usually } \\
\text { reads sports newspapers. He } \\
\text { uses the internet at work and } \\
\text { at home, to watch the news. }\end{array}$ & $\begin{array}{l}\text { He uses it to watch the news } \\
\text { and for entertainment. }\end{array}$ \\
\hline Romeu & 47 & $\begin{array}{l}\text { PhD; university } \\
\text { Professor }\end{array}$ & $\begin{array}{l}\text { Facebook; "news } \\
\text { about politics" }\end{array}$ & $\begin{array}{l}\text { At home there is television, } \\
\text { books, CDs, DVDs, digi- } \\
\text { tal games; rarely are there } \\
\text { printed newspapers. }\end{array}$ & $\begin{array}{l}\text { He uses the internet every day } \\
\text { for work, and for leisure. }\end{array}$ \\
\hline Dina & 53 & $\begin{array}{l}\text { Completion of } \\
\text { Middle School; } \\
\text { cleaner }\end{array}$ & $\begin{array}{l}\text { internet; mobile } \\
\text { phone }\end{array}$ & $\begin{array}{l}\text { At home there is television and } \\
\text { books: school books, novels, } \\
\text { books on architecture, the Bible } \\
\text { (and other religious books). } \\
\text { She reads informational } \\
\text { magazines (which she collects } \\
\text { when she cleans at a public } \\
\text { transportation company). }\end{array}$ & $\begin{array}{l}\text { She does not use it. She has an } \\
\text { old mobile phone only for calls, } \\
\text { especially from her children, } \\
\text { without Internet access. }\end{array}$ \\
\hline
\end{tabular}

\begin{tabular}{ll}
\hline Justina & $46 \quad \begin{array}{l}\text { Completion of } \\
\text { Lower Secondary } \\
\text { education; curren- } \\
\text { tly unemployed }\end{array}$
\end{tabular}
At home there is television, computer (which she hardly uses), books, CDs, comic books, films. She does not buy newspapers. She uses the internet on the mobile phone autonomously. Note: The daughter differed in the references to books made by the mother.

"Sad news"; economic constraints also mean she has to manage her expenses
She looks at the newspaper Correio da Manhã online. She uses the mobile phone autonomously. 


\begin{tabular}{|c|c|c|c|c|c|}
\hline Rita & 16 & $11^{\text {th }}$ grade; student & $\begin{array}{l}\text { For family rea- } \\
\text { sons she cannot } \\
\text { always access the } \\
\text { internet and the } \\
\text { mobile phone. } \\
\text { This makes her } \\
\text { almost forget } \\
\text { they are there } \\
\text { and she adjusts } \\
\text { her daily life to } \\
\text { do without them }\end{array}$ & $\begin{array}{l}\text { There are books in her room, } \\
\text { and she reads a lot. At home } \\
\text { there are films, CDs and a } \\
\text { games console but there is no } \\
\text { internet access. The televi- } \\
\text { sion is in a common space. }\end{array}$ & $\begin{array}{l}\text { There is no internet at } \\
\text { home, so she uses it at } \\
\text { school or in the cafe. }\end{array}$ \\
\hline Olavo & 17 & $9^{\text {th }}$ grade; student & $\begin{array}{l}\text { He does not have } \\
\text { a mobile phone } \\
\text { for economic } \\
\text { reasons }\end{array}$ & $\begin{array}{l}\text { At home, he has television } \\
\text { and books, but he does not } \\
\text { read very much; he watches } \\
\text { films, particularly on his tablet, } \\
\text { which he uses to access the } \\
\text { internet. His mobile phone } \\
\text { broke, and he could not buy } \\
\text { another, and he says he got } \\
\text { used to this situation. }\end{array}$ & $\begin{array}{l}\text { He uses the internet at the } \\
\text { youth centre, at home he uses } \\
\text { a tablet; he does not have a } \\
\text { computer or a mobile phone. }\end{array}$ \\
\hline
\end{tabular}

Table 1: Individual resistances or impossibilities

Of note in this group of adults, who are mainly over the age of 45 , is the resistance to the internet in general, the social network Facebook in particular and certain types of news ("sad news", "political news").

In line with the literature, gender, socio-economic and cultural conditions are also significant factors: those refusing the internet more are mainly women and those in contexts involving economic and cultural deprivation. Although mentioning having "books at home", television remains the dominant medium for entertainment and information. Some people use the internet only for professional reasons, and do not make it part of their lives in other contexts.

The two young people who appear in this table do not refer to rejection, but rather constraints to which they have become accustomed. With a school experience marked by failure, Olavo refers to a poor relationship with reading and enjoys watching films on the digital screen of his tablet, in a home not very well provided for technologically. Rita, with a successful school experience, mentions reading habits and digital media accessible to members of the household, but cannot use the internet at home: her parents have not paid for access fearing that her brother will reassume his online addiction. In both cases, the family context conditions individual choice and communication itself: neither Olavo nor Rita want their parents to participate in the research.

\section{RESISTANCES AND REFUSALS OF FAMILY PAIRS}

When members of two generations coincide in mentioning resistances, let us see if this points to the family transmission of a given cultural component.

Of the five nuclear families in Table 2, two consist of blended families, with the youngest member moving between both households. The level of education among adults is higher than in Table 1, with several different professions. 
Here we can see a clear focus on the rejected medium. Three family pairs refused Facebook and two refused television. No pair rejected the internet in general, pointing to its incorporation as a medium.

Refusing Facebook by the younger member leaves parents - who also do not use it - pleased and young people feel outside of the "flock" of their peers who follow social networks. As regards television, rejection involves highly-educated households and households which on average are rich in media (books, internet, radio, among others). The rejection comes from the parents and is appropriated by the children, in the generational transmission mentioned by Buchner (2003). They also see themselves as being alternative compared to their colleagues.

\begin{tabular}{|c|c|c|c|c|c|}
\hline PARTICIPANT & AGE & $\begin{array}{l}\text { EDUCATION AND } \\
\text { PROFESSION }\end{array}$ & $\begin{array}{l}\text { RESISTANCE/ } \\
\text { REJECTION }\end{array}$ & $\begin{array}{l}\text { MEDIA ENVIRONMENTS } \\
\text { FOR ACCESS TO NEWS }\end{array}$ & INTERNET USES \\
\hline Susana & 54 & $\begin{array}{l}\text { Completed } \\
\text { Secondary } \\
\text { Education; works } \\
\text { at an insurer's }\end{array}$ & $\begin{array}{l}\text { Facebook; } \\
\text { internet }\end{array}$ & \multirow{2}{*}{$\begin{array}{l}\text { At home there are many books, a } \\
\text { desktop computer and a "juras- } \\
\text { sic" phone. They often watch the } \\
\text { news on television and use the } \\
\text { box to watch and record films. }\end{array}$} & $\begin{array}{l}\text { She does not use the internet } \\
\text { very much; mainly at work } \\
\text { and because "she has to". }\end{array}$ \\
\hline António & 19 & $12^{\text {th }}$ grade; student & Facebook & & $\begin{array}{l}\text { He uses the internet, especially } \\
\text { on the computer at home and not } \\
\text { so much on his mobile phone. }\end{array}$ \\
\hline Isabel & 49 & Graduate; nurse & Facebook & \multirow{2}{*}{$\begin{array}{l}\text { In addition to television, there } \\
\text { are three laptops at home, } \\
\text { CDs, DVDs, books and comics. } \\
\text { There are also television and } \\
\text { newspapers. The daughter } \\
\text { says that she loves reading. } \\
\text { The mother says she follows } \\
\text { the news on the internet. }\end{array}$} & $\begin{array}{l}\text { She accesses the internet on } \\
\text { her mobile phone, at home } \\
\text { and at work, for professio- } \\
\text { nal and personal research, } \\
\text { and to follow the news. }\end{array}$ \\
\hline Sónia & 14 & $9^{\text {th }}$ grade; student & Facebook & & $\begin{array}{l}\text { She accesses the internet } \\
\text { on her laptop and mobi- } \\
\text { le phone. She uses it more } \\
\text { at home than at school. }\end{array}$ \\
\hline João & 16 & $\begin{array}{l}\text { Graduate; retired } \\
\text { (social worker) }\end{array}$ & $\begin{array}{l}\text { Facebook; } \\
\text { internet }\end{array}$ & $\begin{array}{l}\text { At home, in addition to television } \\
\text { and radio (always on), there } \\
\text { are books, CDs, DVDs, board } \\
\text { games. In the past, he bought } \\
\text { more newspapers and magazi- } \\
\text { nes than nowadays, for financial } \\
\text { reasons. He considers himself } \\
\text { informed and reads newspapers } \\
\text { and magazines in the library. }\end{array}$ & $\begin{array}{l}\text { He uses the internet mainly } \\
\text { at home and in the libra- } \\
\text { ry; he sometimes uses it } \\
\text { on his mobile phone. }\end{array}$ \\
\hline Rute & 14 & $9^{\text {th }}$ grade; student & Facebook & $\begin{array}{l}\text { In her two houses (paternal and } \\
\text { maternal) she has similar cultural } \\
\text { items; in her mother's house } \\
\text { she has magazines and in her } \\
\text { father's house she has board } \\
\text { games and comic books that } \\
\text { she does not utilize very much. }\end{array}$ & $\begin{array}{l}\text { She accesses the internet in both } \\
\text { homes, through laptops, phone, } \\
\text { and tablet which is the device } \\
\text { she uses the most. She uses her } \\
\text { mobile phone a lot especially for } \\
\text { talking, searching and playing. }\end{array}$ \\
\hline Raquel & 46 & $\begin{array}{l}\text { Graduate; } \\
\text { engineer }\end{array}$ & Television & $\begin{array}{l}\text { At home, there is a radio, a lot } \\
\text { of books, ("everybody reads so } \\
\text { much, they give books as gifts"), } \\
\text { they subscribe to newspapers } \\
\text { and magazines (including foreign } \\
\text { ones and those specifically for } \\
\text { children, such as Visão Junior), } \\
\text { comic books, fashion magazines. }\end{array}$ & $\begin{array}{l}\text { She frequently accesses the } \\
\text { internet on multiple devices. }\end{array}$ \\
\hline
\end{tabular}




\begin{tabular}{|c|c|c|c|c|c|}
\hline Marta & 14 & $\begin{array}{l}9^{\text {th }} \text { grade; } \\
\text { sStudent }\end{array}$ & Television & $\begin{array}{l}\text { She has a radio, many books, } \\
\text { she likes to read, there are } \\
\text { many books in her bedroom. } \\
\text { At home, there are CDs, } \\
\text { movies (old and new). }\end{array}$ & $\begin{array}{l}\text { She uses the internet, on } \\
\text { the phone, on the iPad } \\
\text { and on the computer. }\end{array}$ \\
\hline Miguel & 48 & PhD; Chemist & Television & $\begin{array}{l}\text { At home, there are books, } \\
\text { comic books, he even bought } \\
\text { newspapers and magazines } \\
\text { but for economic reasons } \\
\text { he stopped doing this. }\end{array}$ & $\begin{array}{l}\text { At home he accesses the } \\
\text { internet with a USB pen, on the } \\
\text { laptop (for many years he has } \\
\text { not had a desktop computer) } \\
\text { and on the mobile phone. }\end{array}$ \\
\hline Helena & 17 & $12^{\text {th }}$ grade; student & Television & $\begin{array}{l}\text { At her father's house, she reads } \\
\text { a lot. At her mother's house, she } \\
\text { reads but also watches some } \\
\text { television; sometimes she listens } \\
\text { to music and she has CDs. }\end{array}$ & $\begin{array}{l}\text { At her father's house, she } \\
\text { accesses the internet through a } \\
\text { USB pen, at her mother's house } \\
\text { whenever she wants using Wi- } \\
\text {-Fi and she uses lots of mobile } \\
\text { data on her mobile phone. }\end{array}$ \\
\hline
\end{tabular}

Table 2: Resistances and impossibilities of family pairs

\section{REASONS FOR RESISTANCE OR IMPOSSIBILITY}

\section{DO NOT LIKE AND DO NOT WANT TO USE THIS}

Adults (almost all women and those who are more than 45 years of age) in this thematic group, with different levels of schooling and socio-economic status, have evoked the right to have the choice within a digitalized society, to intentionally refuse something (Neves \& Rente, 2017). If some have to make use of the internet for professional reasons, being on the internet is something all reject because they do not like or do not want to do this.

These vehemently expressed resistances, especially by women with low levels of schooling and unskilled jobs, despite indicating agency and voice, may also hide their inability to use the internet.

Dina, who completed her $6^{\text {th }}$ year of schooling as an adult through the New Opportunities educational programme, does not use the internet by choice. The mobile phone is also a device which she refuses and forgets to use. In a relaxed manner, she described herself as somebody who "switches off". She refuses to go online, even though her children say they would like her to be online and they would help her. However, she tries to be informed. Albeit accidentally, she says she reads articles about technology (their advantages for young people, the dangers they can bring and their capacities in terms of the society of the future), which appear in magazines she collects at the place where she cleans. She likes to read about the matter to be able to follow and talk with her children but refuses the technical support that they would be able to provide her.

Interviewer: Under what conditions do you access computers, the mobile phone, the internet?

Dina: Completely off. Off? Really off?

I: Don't you have a mobile phone?

D: Here's the thing, I have a mobile phone, the simplest of the simplest 
and even then, I can only make calls and sometimes I open messages that they send me, but only if I receive the message and I hear it and see it. Because otherwise I don't pay much attention. No. (...) It's a choice I make. And it's not just that, I really find it difficult, and I don't try to get better... I: For example, what if your children help with this task?

D: They're always trying to help, but I always do other things... (Dina, 53)

Arminda, on the other hand, does not like the fact that she has to use the internet and emails at work.

Interviewer: Where and under what conditions do you access the computer and the internet?

Arminda: Only and exclusively because I have to, I'm against this kind of technology, and I'm talking here about two years back, because previously I refused any company computer. Anything to do with computers, I can say that I have a company mobile phone to receive and make calls [not to send messages], I don't care about anything else. I only use a computer for work at the company and $90 \%$ of that is reading and writing emails. I don't want to go on Google, I don't want anything, it doesn't make me happy, thank God. (Arminda, 59 years old)

Of the two respondents who live in rich media environments, Antónia rejects the internet in a radical manner, and João refuses to overuse it. Already retired as a social worker, João (61 years old) is interested in news and encourages his daughter to read and to use the internet; he uses the internet to search for information that interests him, but has other priorities in his life. He left social networking sites since he considers them a waste of time.

I retired and joined Facebook, but when I realised I was losing endless hours there, I left it. That's not what life is about. When I am interested in something, l'll search for it either in the library or online. For example, a few days ago, a friend lent me a book about a lady called Chimamanda Adichie; it was amazing, I was so fascinated that I went to search [online], I wanted to know more. In utilitarian terms it is very goal-directed. My priority job is my daughter. (João, 61 years old)

Compared to television and radio, especially among older adults, the internet is perceived as being secondary for own use. The same is not the case when they refer to children and grandchildren. Everyone feels that the internet is an important tool for young people and for their children, in particular. As low-skilled members of their generation, they put themselves on the outside but want their descendants digitally integrated.

No, I mean, not the internet. I have the internet because I have a television and I have... the thing is, I have the Internet because I have a phone... But if I do not pay, if they cut off the internet, I won't miss it. But if they cut off the 
water and the power I would miss it. That is why it is essential, what is more essential is water and light. The internet isn't... it's secondary. I mean it's secondary to me, but he [grandson] would miss it. (Antónia, 49 years old)

\section{At THIS STAGE OF LIFE, NO!}

In this group, adult individuals with different levels of schooling reject specific news they dislike, either because it is sad or because it is connected to politics and cause discomfort or disenchantment. The way they express this rejection translates into taking a position they justify due to the stage of life in which they find themselves.

Two women, who stated they became more attentive to information when they became mothers, now refuse to be aware of news that saddens them or may sadden their daughters, with whom they live as single-parent families. Failure to follow the news now seems to be a cocooning strategy.

Another factor which can contribute to this refusal is lack of interest, even if occasional, in topics such as current affairs (Brites, 2015). One of the parents, Romeu, who has a PhD and carries out administrative duties in a higher educational institution, mentions limitations resulting from his decision not to follow either news (an option caused by his disappointment regarding the political situation) or the Facebook network (he is excluded/prevented from disclosing activities as a director and artist).

Reasons for rejecting the news are the following: it is too negative, a point referred to particularly by women with difficult lives, along the lines of what was found by Helgerud (2017), Moeller (1999), Newman et al. (2017), Schrøder and BlachØrsten, 2016; their discredit (Newman et al., 2017); disenchantment with politics (Brites, 2015).

Arminda: I can say that's enough [to the news that makes her sad], I refuse to watch news just because, because I have to feel sorry, to see the child on the beach, so no. I cannot change the world, so why do I have to feel bad if those who can do nothing? Currently there is no selection and anybody of any age can watch, without warning, even children, and I am against that. I think it should be channelled, but maybe they say the news is shocking, but that even makes people more interested. (...) Interviewer: If the news was more positive?

A: Positive, but without deviating from what is happening. In reality, we live in a world of confusion. But I have a right to want to feel good. (Arminda, 59 years of age)

We are faced with a considered and deliberate choice of those who have become accustomed to making choices in the opposite direction to the society in which they live: Arminda considers herself an informed person and a woman who is a fighter. She spoke extensively of her role as a frail woman before 25 April (the Portuguese revolution of 1974) and then later being emancipated, of her struggle for dignity at work and of overcoming her husband's recent death. Despite avoiding negative news, she said that she 
is interested in information on a daily basis and that she likes to talk with her daughter about current affairs.

\section{BETWEEN THE I CANNOT PAY FOR IT AND I CANNOT HAVE IT}

This group is made up of people with low economic resources and family choices where there is no room for dialogue about the use of media and the search for joint solutions. All those in the group adapted their daily lives to the limitations they face. The implications of these turn out to be entangled and to create resistance routines shaping the use of certain media. These are structural constraints external to themselves, which affect what they might have.

The aspect of cost is mentioned by Olavo, 17 who has no mobile phone because his device is damaged and he does not have any way of buying another. Constraints are also seen in situations where economic reasons are indicated in more general terms, such as Justina, unemployed and living on welfare.

The exception to these descriptions involving economic hardship is a young woman, Rita, without internet at home, which causes her to have to use it in cafes and at school. Rita carefully manages what she has to do (personal searches, homework, contacts through email) and controls the time she has to be online. Almost as a consequence, she also avoids her mobile phone, which she no longer considers essential for everyday use. She is very active at school, where she runs activities such as the school radio, and does not give up participating just because she has limited access to the internet.

Interviewer: Where and under what conditions do you access the com-

puter and the internet?

Rita: I don't have the internet at home, because my parents do not want to let me have it. But I usually make use of the computers here at school or when I bring the iPad. Sometimes because of the radio.

I: And on the mobile phone?

$\mathrm{R}$ : The mobile phone is no good for anything. It never works. No battery. I have one, but I don't use it. I also have internet on the tablet when I go to the cafe.

I: And access to the computer?

R: I have a computer at home, a laptop, and when I have homework where I need the internet, either I get the information here at school or I go to the cafe in the afternoon and do everything I need. And then I do the work at home. (Rita, 16 years old)

At a certain point of the interview, Rita considered that this family option could constitute a violation of her human rights - the relationship of the internet and rights was one of the topics of the interview transcript - and set the context for her personal life. Despite this reflection, she points out her position concerning the use of this resource: 
Honestly, if I were a person in revolt against my parents because they did not give me internet access, I would probably get home and use that information against them! And I might still tell them. But for me the internet... Well I live fine without it, I don't have an extreme need to have internet. (Rita, 16 years old)

\section{DON'T WANT TO DRAW ATTENTION TO MYSELF AND DON'T WANT TO GET “HOOKED”}

Young and adult respondents (some of them members of the same family, see Table 2) have shown their rejection of public exposure and the possibility of overconnecting to one medium, which is Facebook. They reject the social network maintaining control over their personal lives and they avoid personal exposure. In their consideration they are refusing what they already know and criticizing how it is conceived; there is a self-regulating strategy to avoid the media becoming something too invasive (Syvertsen, 2017, p. 98).

I have refused Facebook, I have already participated in a network, MySpace. (...) But I left recently, because belonging to a social network implies going there regularly, and I've got so many things to do, I don't want one more. It disturbed me having to deal with this obligation... (Romeu, 47 years old)

The mobile phone is on, but I do not have Facebook. I feel this even because of the children, because they are always on it, the "faces", etc. I try to fight it at home, like at mealtimes to see if we can share, have a dialogue, otherwise... it is an invasion of our space. (Filipe, 45 years old)

In the cases where there is a rejection of Facebook by young people, their parents express relief that the younger members make the same choice. The older adults are keen to point out that they had no influence over their children's decision to reject Facebook. In younger members, this intrusion into private life is pointed out as the factor for rejecting the social network, as this family pair noted.

It's not something that really calls my attention... Social networks. The same for my daughters who do not look at it and this was never because I said, "you can't, you can't have that...". No, it was never that way. The older one I think was on Facebook, and then came to the conclusion that... that it was bullshit, that people exposed their lives... It has no interest at all. (Isabel, 49 years old)

I think the concept might not be too bad [Facebook], but in the meantime, people, how should I say it? Especially at my age they have made the website somewhat... it is only for talking about their lives, photos here and there... I don't like it. (Sónia, 14 years old) 
All respondents who rejected Facebook considered the personal, social, and even professional implications of being outside a space where friends, colleagues, and children "meet" - or "sham meet" as they preferred to describe it. They perceive that whoever is in the network tries to capture them, in the sense of being able to share more and to contact them more. These refusals also imply an option of being on the edge. This is the case with António, who became very addicted to the internet and networks, but who nowadays refuses to be part of Facebook.

António: I do not mind [not using Facebook]. I've already been told that I could not have Facebook and stuff like that, but let me tell you the truth, it doesn't bother me.

Interviewer: You don't care?

A: No, I don't give a crap about it. (António, 19 years old)

\section{DOING SOMETHING DIFFERENT AND DOING IT BETTER}

In this group, the resistance to television is connected to an actual refusal and conscious choice with elements of strong cultural concerns, which is expressed in family micro cultures (Buchner, 2003). They may own this device, but they reject its use with the argument that they can talk more as a family or carry out cultural interests that would be difficult to achieve if everyday life was determined by the television.

These are family environments rich in media, in books and in different forms of culture including an interest in following current affairs (see Table 2). This refusal comes from the adults in the family and is followed by the younger members.

They are neither linear nor coincident options. In family 1 , the mother Raquel and her husband often wonder about whether watching television, especially the news, is the best way to ensure a culturally and civically richer education, especially given important issues such as the economic crisis and terrorist attacks. In family 2, a blended family, the daughters do not have television in the week in which they are living with their father. Miguel, the father, does not question the advantages of not having television, and Helena, the daughter, is also satisfied with the choice. She uses the television at her mother's house for watching the news - she is very critical of television's choices regarding news - and enjoys discussing political issues with her father.

Family 1 :

this [not using television] has a snag, there's not only advantages, for example when it came to the issue of refugees, everyone talked about it and my daughters were not aware of it. (...) As we end up not watching television, there is a gap there. (...) on the internet there has to be some discipline, right? On the television, news is on at that time, on the internet you have to be more disciplined when searching. I have so many items in my diary, that I'm not sure if I should set a time every day to watch the news. [laughs]. (Raquel, 46 years old) 
Marta: I've had television. I mean, I had a television at home, but I only had the four [terrestrial] channels, and I only had all the channels when I was probably in the second year, or... First, second year, I'm not sure anymore. Interviewer: Who chose not to have television? I imagine it might have been your parents...

M: I do not know. I think we... I remember when they went there to install the television... We had moved out of the house about two years before and... [they thought they did not have room for the television and chose to stop watching]. (Marta, 14 years old)

Family 2:

The only thing that... the only thing that made me think for a while was the good things that television has, especially cable. And so, but there is one channel at least, TV2 on our open access television, on our public television, that broadcasts some quality content. Everything else for me is very limited, too much and that does not justify having a television at home. So, I never feared this... My daughters are perfectly informed, they do not miss out on anything, I think you only gain by not having a television. (Miguel, 48 years old)

When I watch the news on television, especially the Portuguese channels [in my mother's house or programmes on the internet personally chosen], I think it's very much aimed at the type of sensation which they want to generate in us, for example, that thing in Paris, I thought it was a little ridiculous... for weeks it was always Paris, Paris, Paris and then people were not lucky or don't have that, I don't know, don't have the opportunity to search for and listen to other sources they think that only that had happened. And they don't know about other attacks or other things that are happening not only in Europe, and that is only centred on our little world. So, in that sense, I consume that. At the level of the internet and virtual platforms, I watch... On the internet I watch news at the level of what's going on, you know, the social level, in the world, not so political, human rights, all that. (Helena, 17 years old)

Both the adults and younger members consider this refusal of television positive. There are parents worried about what is lost in terms of socialization, as schoolmates talk about news that meets the schedule determined by television. The younger members feel special, and are also seen as special by their colleagues. One of the girls in family 2 is seen by her classmates as the most highbrow in the class. 


\section{ConClusions}

Noting the deeply mediatized nature of contemporary societies and considering particular aspects of the Portuguese context, this exploratory study analysed the ways in which 18 respondents, including family members of different generations, showed signs of resistance and or of being unable to enjoy the media. In some cases, these signs were related to the internet and came only from one of the family members, almost always from the older generation, women and those with low levels of schooling, reproducing an already identified pattern (Ponte, 2011). In others, parents and children demonstrated common practices rejecting the hegemonic social network, Facebook, indifference to television and having a common interest in seeking alternatives to be informed and to enjoy media entertainment.

As such, we did not find a global rejection of the media but resistances and constraints, shown in different ways, which could be singular or plural. Resistances come up against professional contexts where, even if one wishes to, one cannot stop using these.

The two expressions, not wanting to and not being able to, point to different but equally consequential behaviors. The lack of cultural capital (Bourdieu, 2003) can lead to fear of use, and thus this shows a not being able to due to lack of skills. The tiredness and disenchantment related to a certain phase of life or economic condition of life, and a wish to affirm a social difference, are also clear. The resistance to a certain type of news information was stated more by mothers and fathers, coupled with a certain desire to ignore what they did not consider to be within their power to change. Among young people and families with more resources, the desire for information is clearly encouraged by the family environment, but it can also be encouraged by the dynamics of civic participation in a school context (Brites, 2015).

Generational dynamics are evident both in situations which show rejection of the internet by adults, even with the encouragement of younger members - who here subvert the traditional transmission processes - as in family pairs where the habitus of the younger members clearly arises from the environment in which they grew up - as is the case with indifference to television.

It is also important to note the decision-taking which results from an assessment of previous experience, such as abandoning a social network. We would say that effort must be exerted to carry out a resistance or rejection to what constitutes the dominant pattern in media practices. With regard to social networks, an awareness of the right to have a choice in the digitized society prevailed. When stating the pressure to be part of the social network where all the Portuguese internet users are, it is nonetheless symptomatic of this effort that it is the Facebook social network which is the medium which obtained the largest number of references.

In addition to motivation in a positive sense, we noted other more negative feelings, such as subjugation. These are resistances and rejections due to structural factors (family imposition) and socioeconomic situation (classical exclusion). In these cases, there was a strategy of adapting to the existing limitation of media use. 
These results indicate that knowing how to choose requires skills, which are not always facilitated. If this aspect has been developed in relation to media consumption, we can also state that refusing and rejecting depends on various factors, such as cultural resources and media competencies to make a critical and aware choice, in a society governed by the voracity of the media.

Translation: David Hardisty

\section{ACKNOWLEDGEMENTS}

This work was funded through the Science and Technology Foundation (SFRH / BPD / 92204/2013). Financed by FCT - Foundation for Science and Technology within the framework of the project UID/CCl/4667/2016; and by National Funds through the FCT - Foundation for Science and Technology within the framework of the project Ref. ${ }^{a}$ UID/CCl/04667/2016 - Center for Research in Communication, Information and Digital Culture.

\section{REFERENCES}

Amado, J., Costa, A. P. \& Crsoé, N. (2014). A técnica da análise de conteúdo. In J. Amado (Ed.), Manual de investigação qualitativa em educação (pp. 301-350). Coimbra: Imprensa Universidade de Coimbra.

Araújo, E., Cogo, D. \& Pinto, M. (2015). Mobilidades, media(ções) e cultura. Comunicação e Sociedade, 28, 7-14. DOI: $10.17231 /$ comsoc.28(2015).2267

Attride-Stirling, J. (2001). Thematic networks: an analytic tool for qualitative research. Qualitative Research, 1(3), 385-405. DOI: 10.1177/146879410100100307

Bardin, L. (2009). Análise de conteúdo. Lisbon: Edições 70.

Beck, U. (1997). Democratization of the family. Childhood, 4(2), 151-168. DOI: 10.1177/0907568297004002002

Beck, U. \& Beck-Gernsheim, E. (2002). Individualization: institutionalized individualism and its social and political consequences. London, Thousand Oaks and New Delhi: Sage.

Bourdieu, P. (2003). Questões de Sociologia. Lisbon: Fim de Século.

Brites, M. J. (2015). Jovens e culturas cívicas: Por entre formas de consumo noticioso e de participação. Covilhã: LabCom Books.

Buchner, P. (2003). The transmission of social and cultural capital between family generations. In B. Mayall \& H. Zeiher (Eds.), Childhood in generational perspective (pp. 71-85). London: Institute of Education.

Burnay, C. \& Ribeiro, N. (2016). As novas dinâmicas do consumo audiovisual em Portugal. Lisbon: ERC.

Castells, M. (2008). The new public sphere: global civil society, communication networks, and global governance. The ANNALS of the American Academy of Political and Social Science, 616(1), 78-93. DOI: $10.1177 / 0002716207311877$

Corbin, J. \& Strauss, A. (1990). Grounded theory research: procedures, canons, and evaluative criteria. Qualitative Sociology, 13(3), 3-21. DOI: 10.1007/BFoog88593 
Couldry, N. \& Hepp, A. (2017). The mediated construction of reality. Cambridge, USA: Polity Press.

Dijck, J. v. (2013). The culture of connectivity: a critical history of social media. Oxford: Oxford University Press.

Elias, N. (1987). A sociedade dos indivíduos. Lisbon: Publicações D. Quixote.

Helgerud, A. (2017). Sjeldenkonsumenter av nyheter: Holdning til nyhetsmedier, medborgerskap og forklaringer på sjeldenkonsum blant unge voksne. Norsk medietidsskrift, 24(2), 1-19. doi:10.18261/ ISSN.0805-9535-2017-02-04

Hepp, A. \& Hasebrink, U. (2018). Researching transforming communications in times of deep mediatization: A figurational aproach. In A. Hepp, A. Breiter, \& U. Hasebrink (Eds.), Communicative figurations: transforming communications in times of deep mediatization (pp. 15-50). Gewerbestrasse: Palgrave.

Jenkins, H. (2006). Convergence Culture: where old and new media collide. New York and London: New York University Press.

INE. (2015). Sociedade da Informação e do Conhecimento - inquérito à utilização de tecnologias da informação e da comunicação nas famílias: a participação em redes sociais é mais frequente em Portugal do que na EU. Retreived from http://smi.ine.pt/SuporteRecolha/Detalhes/?id=10246\&lang=PT

Krotz, F. (2009). Mediatization: a concept with which to grasp media and societal change. In K. Lundby (Ed.), Mediatization: concepts, changes and consequences (pp. 24-40). New York: Peter Lang.

Livingstone, S. (2014). The mediatization of childhood and education: reflections on the class... In L. Kramp, N. Carpentier, A. Hepp, I. T. Trivundža, H. Nieminen, R. Kunelius, T. Olsson, E. Sundin \& R. Kilborn (Eds.), Media practice and everyday agency in Europe (pp. 55-68). Bremen: Edition Lumière.

Milner, H. (2002). Civic literacy: how informed citizens make democracy work. Hanover and London: Tufts University.

Moeller, S. D. (1999). Compassion fatigue: how the media sell disease, famine, war and death. New York and London: Routledge.

Neves, B. B. \& Rente, R. (2017).Não alinhados? Jovens não utilizadores de sites de redes sociais. Sociologia Problemas e Práticas, 85, 107-129. DOI: 10.7458/SPP2017856943

Newman, N., Fletcher, R., Kalogeropoulos, A., Levy, D. A. L. \& Nielsen, R. K. (2017). Reuters Institute digital news report 2017. Retrieved from https://tinyurl.com/yarldolr

Obercom (2017). Reuters Institute - Digital news report 2017 Portugal. Retrieved from https://obercom.pt/wpcontent/uploads/2017/12/2017-Reuters-Institute-DNR-PT.pdf

Ponte, C. (2011). Uma geração digital? A influência familiar na experiência mediática de adolescentes. Sociologia - Problemas e Práticas, 65, 31-50. Retrieved from http://www.scielo.gpeari.mctes.pt/pdf/spp/ n65/n65ao2.pdf

Postman, N. (1985/2005). Amusing ourselves to death. Londron: Penguin Books.

Putnam, R. D. (2000). Bowling alone: the colapse adn revival of American community. New York: Simon \& Schuster.

Schrøder, K. C. \& BlachØrsten, M. (2016). The nature of news avoidance in a digital worlddigital news report 2016. Retrieved from http://www.digitalnewsreport.org/essays/2016/ nature-news-avoidance-digital-world/ 
Seale, C. (2004). Generating grounded theory. In C. Seale (Ed.), Researching society and culture. Los Angeles, London, New Delhi and Singapura: SAGE.

Syvertsen, T. (2017). Media resistance: protest, dislike, abstention. Gewerbestrasse: Palgrave.

Woodstock, L. (2014). Media resistance: opportunities for practice theory and new media research. International Journal of Communication, 8(2014), 1983-2001. Retrieved from https://ijoc.org/index.php/ ijoc/article/view/2415

\section{BIOGRAPHICAL NOTES}

Maria José Brites is Associate Professor at the Faculty of Communication, Architecture, Arts and Information Technologies, at the Universidade Lusófona do Porto.

ORCID: https://orcid.org/oooo-0002-9840-9554

Email: britesmariajose@gmail.com

Address: Rua Augusto Rosa, n²4, 4000-098, Porto-Portugal

Cristina Ponte is Associate Professor at the Department of Communication Sciences of the Faculty of Social Sciences and Humanities of the NOVA University of Lisbon (NOVA FCSH).

ORCID: https://orcid.org/oooo-0oo2-1534-4784

Email: cristina.ponte@fcsh.unl.pt

Address: Av. De Berna, 26-C, 1069-061, Lisboa - Portugal

* Submitted: 12.04.2018

*Accepted: 23.07.2018 